\title{
Original Paper \\ Reproductive phenology and influence of abiotic variables for two mangrove species in northeastern Brazil
}

\author{
Frederico Lage-Pinto ${ }^{1,2}$, Pedro Silva Fernando ${ }^{1,3}$, Alan Felix Meyer Carletto ${ }^{1,4}$ \& Elaine Bernini ${ }^{1,5,6}$
}

\begin{abstract}
Information on plant phenological patterns aids in understanding the structure and functioning of ecosystems and support restoration projects in degraded areas. The aim of this study was to characterize the reproductive phenology of Avicennia germinans and Laguncularia racemosa in a mangrove forest in the Mamanguape River estuary in northeastern Brazil. The characterization was performed monthly from July 2016 to June 2017. We applied circular statistics to detect seasonal trends, calculated intra-specific synchrony, and performed regressions between the reproductive phenophases and the abiotic variables. Avicennia germinans exhibits seasonal responses to floral buds, flowers at anthesis, and fruit, with one reproductive episode per year (annual pattern). Laguncularia racemosa has no seasonal response, with one reproductive episode per year for floral buds (annual pattern) and two episodes for flowers at anthesis and fruits (subannual pattern). Reproductive phenophases of $A$. germinans exhibited higher intra-specific synchrony than L. racemosa. We provide evidence that temperature, solar radiation and rainfall are important drivers of the flowering rhythm in both species. In conclusion, the results of this study showed that the species exhibited different phenological responses, even though they were subjected to the same abiotic conditions.
\end{abstract}

Key words: Avicennia germinans, flowering, fruiting, Laguncularia racemosa.

\section{Resumo}

Informações sobre padrões fenológicos das plantas ajudam a entender a estrutura e o funcionamento dos ecossistemas e apóiam projetos de restauração em áreas degradadas. O objetivo deste estudo foi caracterizar a fenologia reprodutiva em indivíduos de Avicennia germinans e Laguncularia racemosa em uma floresta de mangue no estuário do rio Mamanguape, Nordeste do Brasil. O registro foi realizado mensalmente de Julho 2016 a Junho 2017. Aplicamos estatística circular para detectar tendências sazonais, calculamos a sincronia intra-específica e realizamos regressões entre fenofases e variáveis abióticas. Avicennia germinans exibiu respostas sazonais para botões florais, flores em antese e frutos, com um episódio reprodutivo por ano (padrão anual). Laguncularia racemosa não mostrou resposta sazonal, com um episódio por ano para botões florais (padrão anual) e dois episódios para flores em antese e frutos (padrão subanual). As fenofases reprodutivas de $A$. germinans apresentaram maior sincronia intra-específica do que $L$. racemosa. Fornecemos evidências de que a temperatura, a radiação solar e a precipitação são fatores importantes para o ritmo da floração em ambas as espécies. Em conclusão, os resultados deste estudo mostraram que as espécies exibiram diferentes respostas fenológicas, mesmo estando submetidas às mesmas condições abióticas.

Palavras-chave: Avicennia germinans, floração, frutificação, Laguncularia racemosa.

\footnotetext{
${ }^{1}$ Federal University of Paraíba, Laboratory of Coastal and Ocean Ecology, Campus IV, Litoral Norte, Centro, Rio Tinto, PB, Brasil.

${ }^{2}$ ORCID: <https://orcid.org/0000-0002-7963-1539>.

${ }^{3}$ ORCID: <https://orcid.org/0000-0003-1024-5346>.

${ }^{4}$ ORCID: $<$ https://orcid.org/0000-0001-7539-5340 >.

${ }^{5}$ ORCID: < https://orcid.org/0000-0002-5215-6766>.

${ }^{6}$ Author for correspondence: elainebernini@hotmail.com
} 


\section{Introduction}

Reproductive phenology of tropical plants and its dependence on abiotic factors have been analyzed for several ecosystems (Morellato et al. 2013; Rodríguez-Gallego \& Navarro 2015; Ulsig et al. 2017). Knowledge on phenological patterns provides information on the quality and quantity of available resources for fauna (Fenner 1998; Morellato et al. 2016), aids in understanding ecosystems structure and functioning (EncinasViso et al. 2012; Revilla et al. 2014), support restoration projects in degraded areas (Zamith \& Scarano 2004; Garcia et al. 2009), and can be used to monitor climate change (Morellato 2008).

Complex interactions between abiotic and biotic factors control plant reproductive phenology (Wolkovich et al. 2014). Abiotic factors include rainfall, the air temperature, and solar radiation (Nadia et al.2012; Couralet et al. 2013; Wolkovich et al. 2014; Borchert et al. 2015), whereas biotic factors are related to pollinators, dispersers, and morphological/physiological adaptations (Liebsch \& Mikich 2009; Wolkovich et al. 2014).

Reproductive phenology of the mangrove species has been successfully associated with abiotic factors. Nadia et al. (2012) showed that rainfall and temperature drive the flowering and fruiting rhythm of the mangrove species. Van der Stocken et al. (2017) demonstrated significant correlations between mangrove propagule release and rainfall, with $72 \%$ of the studies showing propagule release during the wet season, except for southernmost latitudes. However, in some cases the reproductive phenophases of mangrove species has exhibited little or no relationship with abiotic variables (Wang'ondu et al. 2013; Kamruzzaman et al. 2019).

Adaime (1985) conducted the first study in Brazil on the flowering and fruiting patterns of the mangrove species and their relationship with abiotic factors to estimate mangrove primary productivity. A growing number of studies on reproductive phenology and its relationship with abiotic (e.g., Fernandes 1999; Nadia et al. 2012; Medeiros \& Sampaio 2013; Alvarenga 2015; Cardoso et al. 2015) and biotic factors (Nadia et al. 2012) have subsequently been published, although the study areas have been distributed irregularly along the coast.

The mangrove forests of the Mamanguape River estuary are considered the largest and bestpreserved mangrove forests in Paraíba state in northeastern Brazil. This ecosystem is within the Barra de Mamanguape Environmental Protection Area but has been degraded by vegetation removal for the installation of shrimp farming tanks, resource overexploitation, intruding livestock production, urbanization, and intensive selective cutting. In the upper Mamanguape River estuary, a large clearing has resulted from intensive selective cutting. Severe defoliation of Avicennia germinans (L.) L. (Acanthaceae) by the caterpillars of a lepidopteran species led the local population to conclude that the plants were dead and begin logging. The Laguncularia racemosa (L.) C.F. Gaertn. (Combretaceae) trees that also occurs in this area were not affected by severe defoliation but they were also targeted for selective cutting. The conservation unit management plan recommends the restoration of this degraded forest (ICMBio 2014), but studies are needed to support forest restoration actions.

Within this context, the objective of this study was to characterize of the reproductive phenology of $A$. germinans and $L$. racemosa in the mangroves of the Mamanguape River estuary to answer the following questions: (1) Do these species flower and fruit seasonally? (2) Do reproductive patterns vary between species? (3) Do reproductive phenophases exhibit intraspecific synchrony and depend on abiotic factors? Phenological information, which is required to understand the geographic variability of phenological responses to environmental factors, remains scarce for many tropical trees. The results from this study represent the first record of the reproductive phenology of mangrove species in Paraíba state.

\section{Materials and Methods}

Study area and species studied

This study was conducted in a mangrove forest in the upper Mamanguape River estuary $\left(06^{\circ} 49^{\prime} 16^{\prime \prime} \mathrm{S}, 35^{\circ} 03^{\prime} 44^{\prime \prime} \mathrm{W}\right)$ in the Barra do Rio Mamanguape Environmental Preservation Area (Decree No. 924/93), on the northern coast of Paraíba state, northeastern Brazil. The regional climate is tropical and humid (Am, in the Köppen classification), and the average annual temperature varies between $24{ }^{\circ} \mathrm{C}$ and $26{ }^{\circ} \mathrm{C}$ (Alvares et al. 2013). Total annual precipitation ranges between 1,600 and 1,900 mm (Alvares et al. 2013), and the rainy season spreads from February to August.

The mangrove forest in the Mamanguape River estuary covers approximately $45.6 \mathrm{~km}^{2}$ and is 
composed of Avicennia germinans, A. schaueriana Stapf \& Leechm. ex Moldenke, L. racemosa, and Rhizophora mangle L. Only A. germinans and L. racemosa were recorded in the study area, which form forests with a mean canopy height ranging from 1.4 to $11.1 \mathrm{~m}$, a mean diameter at breast height ranging from 0.8 to $21.6 \mathrm{~cm}$, a mean basal area ranging from 1.5 to $16.2 \mathrm{~m}^{2} /$ ha, and mean density of 15 to 1,331 individuals/ha (Nascimento-Costa 2015). The Avicennia germinans tree is known the black mangrove and thrives under a wide variety of topographic conditions and interstitial salinity. The Laguncularia racemosa tree is known as white mangrove and develops mainly at high elevations with low flood frequencies.

\section{Phenological monitoring}

Reproductive phenology was monitored monthly from July 2016 to June 2017. Sixteen individuals of each species ( $>2 \mathrm{~m}$ tall) were tagged along a track (following Morellato et al. 2010). The intensity of each reproductive phenophase was assessed by the Fournier intensity index (Fournier 1974), wherein a value of 0 was assigned in the absence of a phenophase, and phenophases were assigned values from 1 to 4 in $25 \%$ intervals ( $1=$ $1-25 \% ; 2=26-50 \% ; 3=51-75 \% ; 4=76-100 \%$ ). The following phenophases were considered: floral buds, flowers at anthesis, and fruits (immature and mature).

Precipitation and temperature data for the study area $\left(06^{\circ} 49^{\prime} 16^{\prime \prime} \mathrm{S}, 35^{\circ} 03^{\prime} 44^{\prime \prime} \mathrm{W}\right)$ were obtained from the Climatic Research Unit at the University of East Anglia (Harris \& Jones 2020). Solar radiation data were obtained from the NASA website (NASA 2020).

\section{Data analysis}

The phenological response of the phenophases was classified according to Newstrom et al. (1994), and the synchrony index was calculated according to Augspurger (1983) using the 'flower' package (Wang 2015) of R software (R Development Core Team 2018).

Bencke \& Morellato (2002) have recommended the combined use of two methods to estimate and represent species-level phenological data and accurately differentiate between activity and intensity peaks. Therefore, Fournier intensity index data were used to quantify the activity index (in terms of presence and absence). To test the null hypothesis that the phenophases were uniformly distributed through time, Rao's spacing test was used because it is less sensitive to multimodal data (Jammalamadaka \& SenGupta 2001). After visual analysis of data distribution, seasonality was assessed by Rayleigh test (Morellato et al. 2000; Zar 2010) only for $A$. germinans that presented unimodal data. Circular statistics were performed by R software, using functions from the 'circular' package (Agostinelli \& Lund 2017). Circular distributions were visualized using Oriana 4.02 software (Kovach 2011).

A stepwise multiple regression analysis was performed to determine whether the activity index data for each phenophase were related to the following abiotic factors: solar radiation, temperature, and rainfall (considering no time lag, a one-month time lag, and a two-month time lag). Final model selection was accomplished in $\mathrm{R}$ software through forward or backward elimination stepwise regression ( $\alpha=0.05)$ that generated the lowest Akaike information criterion (AIC) score.

\section{Results}

During the study period, the most intense solar radiation was recorded from September to November (Fig. 1). The lowest and highest mean air temperatures were recorded in July $\left(24.9^{\circ} \mathrm{C}\right)$ and February $\left(27.5^{\circ} \mathrm{C}\right.$; Fig. 1), respectively. The lowest rainfall values were recorded from September to November, and the highest rainfall values were recorded from April to June (Fig. 1).

Avicennia germinans exhibited high intraspecific synchrony (Tab. 1). This species showed an annual (only one reproductive episode per year) and a seasonal response for floral buds, flowers at anthesis, and fruits (Fig. 2). The highest flowering

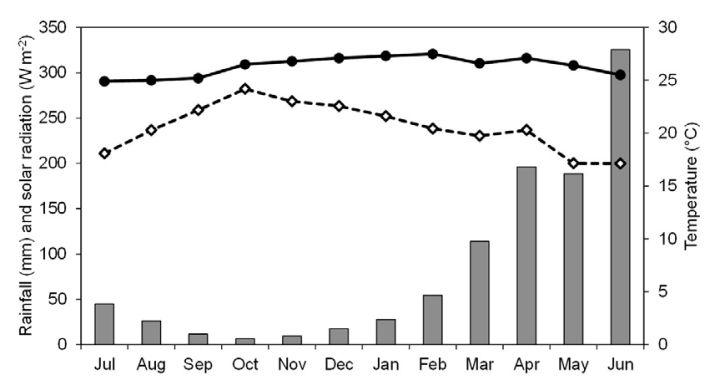

Figure 1 - Precipitation and temperature data (Harris \& Jones 2020), and solar radiation data (NASA 2020) obtained for the study area in a mangrove in the Mamanguape River estuary (July/2016 to June/2017). Open diamonds $=$ solar radiation; Closed circles $=$ air temperature; Gray bars = rainfall. 
Table 1 - Synchrony index and results of the circular statistical analysis for the activity index calculated for the reproductive phenophases of two mangrove species in the Mamanguape River estuary.

\begin{tabular}{lccccccc}
\hline & \multicolumn{3}{c}{ Avicennia germinans } & & \multicolumn{3}{c}{ Laguncularia racemosa } \\
\cline { 2 - 3 } \cline { 7 - 8 } & Bud & Flower & Fruit & & Bud & Flower & Fruit \\
\hline Synchrony index $(\mathrm{Z})$ & 0.90 & 0.94 & 0.94 & & 0.82 & 0.73 & 0.85 \\
Mean angle & $305.36^{\circ}$ & $311.26^{\circ}$ & $65.67^{\circ}$ & & - & - & - \\
Angular standard deviation & $46.99^{\circ}$ & $49.92^{\circ}$ & $37.54^{\circ}$ & & - & - & - \\
Mean date & $6 \mathrm{Nov}$ & $12 \mathrm{Nov}$ & $7 \mathrm{Mar}$ & & - & - & - \\
Length of the mean vector $(\mathrm{r})$ & 0.71 & 0.68 & 0.81 & & - & - & - \\
Rao test $(P)$ & $<0.001$ & $<0.001$ & $<0.001$ & $<0.001$ & $<0.001$ & $<0.001$ \\
Rayleigh test $(P)$ & $<0.001$ & $<0.001$ & $<0.001$ & & - & - & - \\
\hline
\end{tabular}

intensity occurred during the dry season, whereas fruiting was more intense in the transition period between the dry and rainy seasons (Fig. 2). The total duration of flowering was eight months and that of fruiting was six months; in both cases this duration is classified as extended (Newstrom et al. 1994). The phenophases showed non-uniform distribution (Tab. 1). The mean activity index for floral buds, flowers at anthesis, and fruits
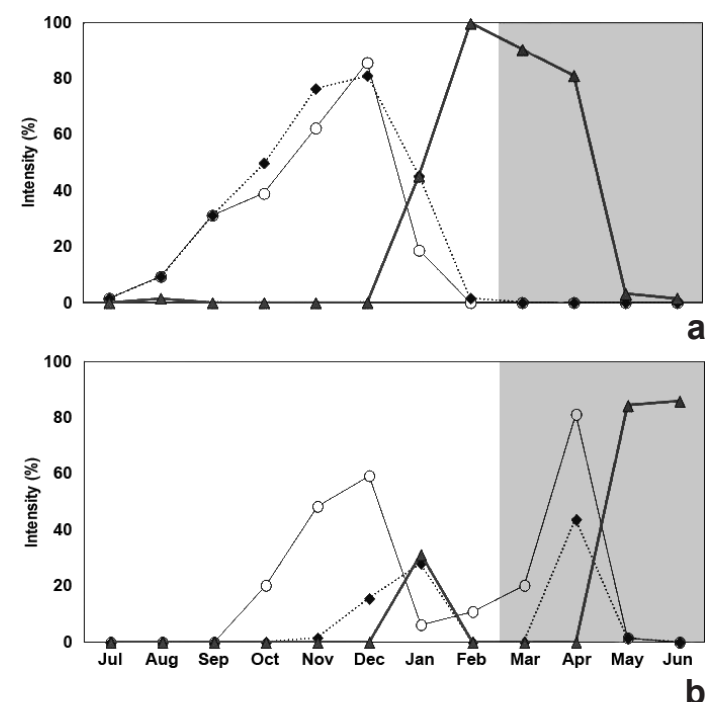

Figure 2 - $a-b$. Fournier intensity percentage for reproductive phenophases in a mangrove in the Mamanguape River estuary - a. of Avicennia germinans; b. of Laguncularia racemosa. Open circles = floral buds; Closed diamonds = flowers at anthesis; Gray triangles = fruits; the shaded area indicates the rainy season. showed significant seasonality, with mean dates in November, November and March, respectively (Tab. 1; Fig. 3). Phenophases were associated with at least two of the abiotic variables, either in the month of their occurrence or in the previous months in A. germinans (Tab. 2). The floral bud and fruits were associated with all abiotic variables, whereas flowers at anthesis were associated with temperature and solar radiation.

The synchrony values for Laguncularia racemosa were high, albeit smaller than those for A. germinans (Tab. 1). An annual phenological pattern for floral buds and a subannual pattern (two reproductive episodes per year) for flowers at anthesis and fruits were observed for $L$. racemosa (Fig. 2). Although flowering and fruiting occurred in both the rainy and dry seasons, the highest intensity was recorded in the rainy season. Floral buds were produced during eight months, which again is classified as a extended duration (Newstrom et al. 1994). Flowers in anthesis episodes were present for a period lasting between two and three months, and fruiting episodes lasted between one and two months. Although the reproductive phenophases did not exhibit seasonality, flowering and fruiting were concentrated in certain periods, indicating a nonuniform distribution of buds, flowers and fruits throughout the year (Tab. 1; Fig. 3). Phenophases were associated with at least one of the abiotic factors, either in the month of their occurrence or in the previous months in L. racemosa (Tab. 2 ). The floral bud and flowers at anthesis were associated with all abiotic factors, whereas fruits were associated with rainfall in the current month. 


\section{Floral buds}
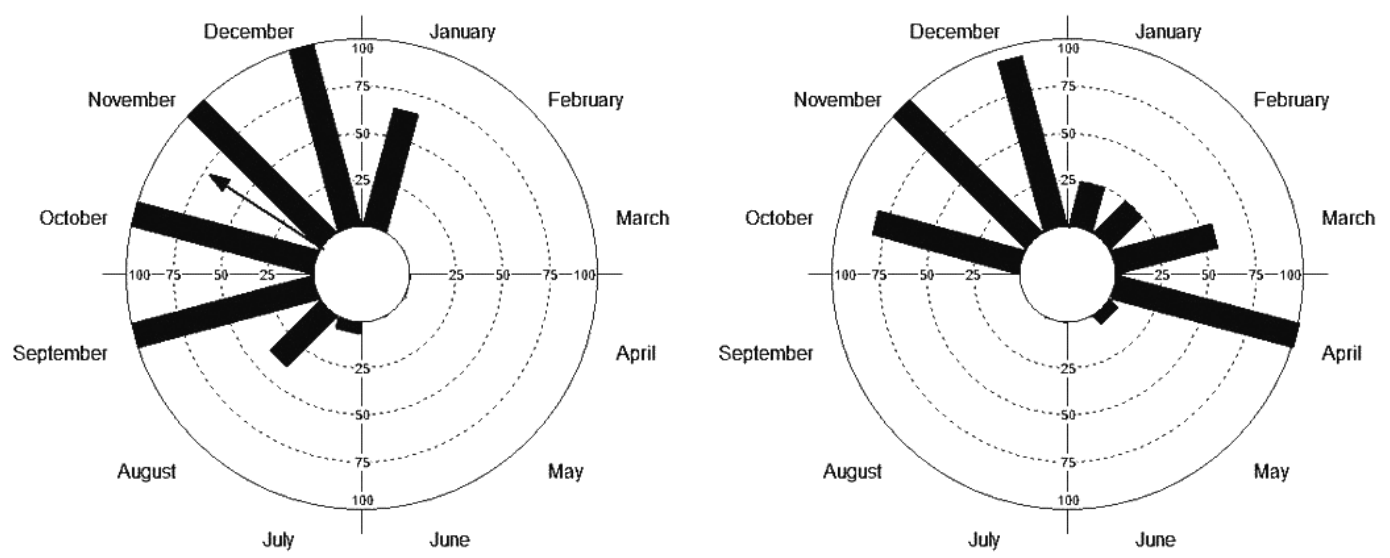

\section{Flowers at anthesis}
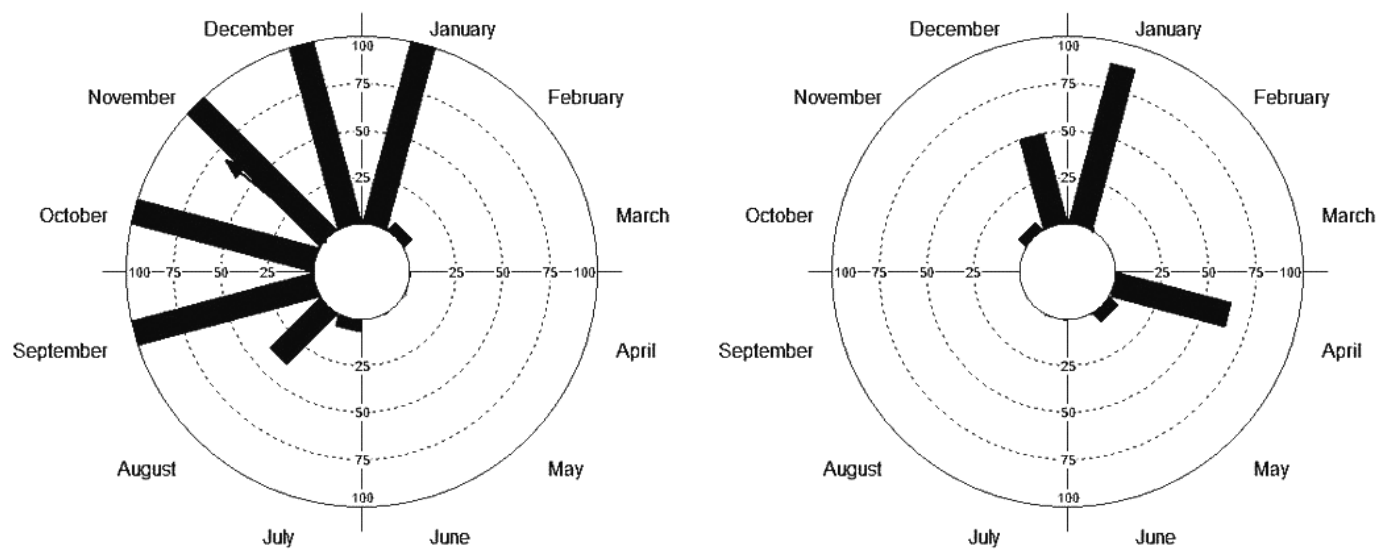

\section{Fruits}
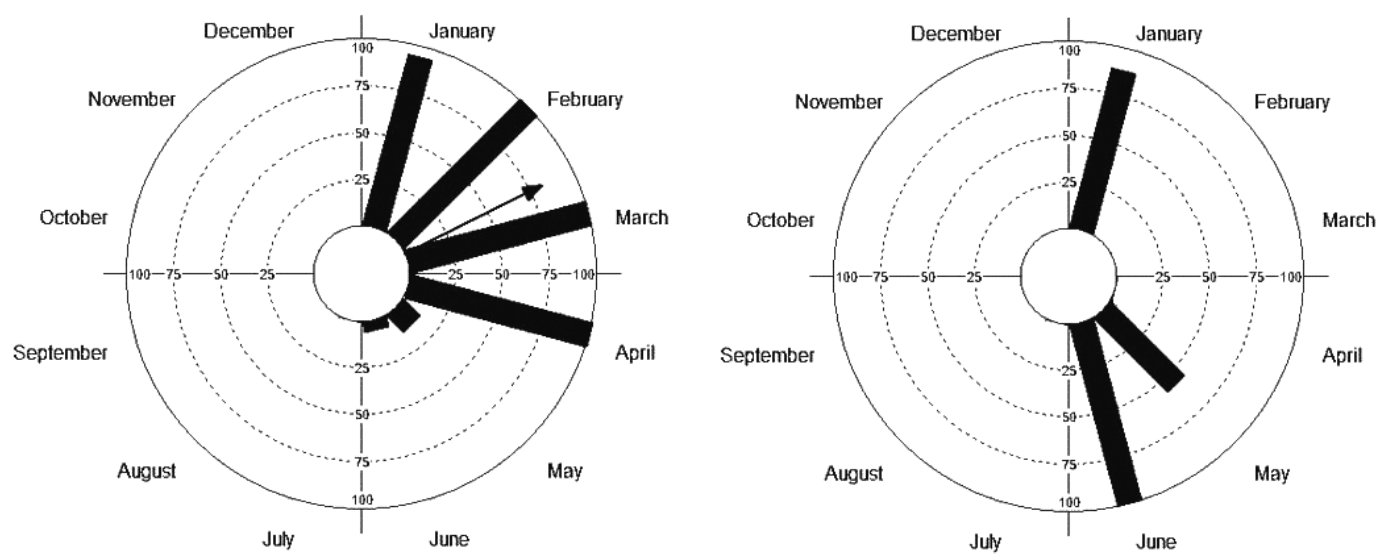

Figure 3 - Circular histograms of activity index of reproductive phenophases of Avicennia germinans (left) and Laguncularia racemosa (right) in a mangrove forest in the Mamanguape River estuary; arrow length reflects $r$ value from 0 to 1 . Arrow direction indicates mean date (mean angle); monthly observations were conducted from July 2016 to June 2017. 
Table 2 - Models used to evaluate the association between abiotic factors and the reproductive phenophases of of Avicennia germinans and Laguncularia racemosa in a mangrove in the Mamanguape River estuary. Numbers after each variable refer to the time lag used in the analyses. $\mathrm{AIC}=$ Akaike information criterion; temp = mean temperature; rain $=$ rainfall; $\operatorname{rad}=$ solar radiation .

\begin{tabular}{|c|c|c|c|c|}
\hline Species / Phenophase & Full Model & AIC & Selected Model & AIC \\
\hline \multicolumn{5}{|l|}{ Avicennia germinans } \\
\hline Bud & $\begin{array}{l}\text { bud } \sim \text { temp } 0+\text { temp } 1+\text { temp } 2+\text { rain } 0+ \\
\operatorname{rain} 1+\operatorname{rain} 2+\operatorname{rad} 0+\operatorname{rad} 1+\operatorname{rad} 2\end{array}$ & 96.0 & $\begin{array}{l}\text { bud } \sim \text { temp } 0+\text { temp } 1+\text { temp } 2+\text { rain } 1+ \\
\text { rain } 2+\operatorname{rad} 2\end{array}$ & 56.0 \\
\hline Flower & $\begin{array}{l}\text { flo } \sim \text { temp } 0+\text { temp } 1+\text { temp } 2+\text { rain } 0+ \\
\text { rain } 1+\operatorname{rain} 2+\operatorname{rad} 0+\operatorname{rad} 1+\operatorname{rad} 2\end{array}$ & 117.8 & flo $\sim$ temp0+temp $1+\operatorname{rad} 1+\operatorname{rad} 2$ & 74.9 \\
\hline Fruit & $\begin{array}{l}\text { fr } \sim \text { temp } 0+\text { temp } 1+\text { temp } 2+\operatorname{rain} 0+ \\
\text { rain } 1+\operatorname{rain} 2+\operatorname{rad} 0+\operatorname{rad} 1+\operatorname{rad} 2\end{array}$ & 108.6 & $\begin{array}{l}\text { fr } \sim \text { temp } 0+\text { temp } 1+\text { temp } 2+\text { rain } 0+ \\
\text { rain } 1+\operatorname{rad} 2\end{array}$ & 66.7 \\
\hline \multicolumn{5}{|l|}{ Laguncularia racemosa } \\
\hline Bud & $\begin{array}{l}\text { bud } \sim \text { temp } 0+\text { temp } 1+\text { temp } 2+\text { rain } 0+ \\
\operatorname{rain} 1+\operatorname{rain} 2+\operatorname{rad} 0+\operatorname{rad} 1+\operatorname{rad} 2\end{array}$ & 124.0 & $\begin{array}{l}\text { bud } \sim \text { temp } 2+\text { rain } 0+\text { rain } 2+\operatorname{rad} 0+ \\
\operatorname{rad} 1+\operatorname{rad} 2\end{array}$ & 83.6 \\
\hline Flower & $\begin{array}{l}\text { flo } \sim \text { temp } 0+\text { temp } 1+\text { temp } 2+\text { rain } 0+ \\
\text { rain } 1+\operatorname{rain} 2+\operatorname{rad} 0+\operatorname{rad} 1+\operatorname{rad} 2\end{array}$ & 118.6 & $\begin{array}{l}\text { flo } \sim \text { temp } 0+\text { temp } 1+\text { temp } 2+\text { rain } 0+ \\
\text { rain } 2+\text { rad } 0+\text { rad } 1\end{array}$ & 79.0 \\
\hline Fruit & $\begin{array}{l}\mathrm{fr} \sim \text { temp } 0+\text { temp } 1+\text { temp } 2+\text { rain } 0+ \\
\text { rain } 1+\text { rain } 2+\operatorname{rad} 0+\operatorname{rad} 1+\operatorname{rad} 2\end{array}$ & 133.3 & $\mathrm{fr} \sim \operatorname{rain} 0$ & 85.2 \\
\hline
\end{tabular}

\section{Discussion}

The results of this study showed that intraspecific synchrony was high for both species, though it was higher in $A$. germinans than in L. racemosa. In the case of flowering, this is important because pollinator attraction and cross-pollination intensify when individuals exhibit high synchrony during flowering (Augspurger 1983). High synchrony in flowering was observed for $A$. schaueriana populations in another mangrove in northeastern Brazil (Nadia et al. 2012) and for A. germinans in mangroves in the north and northeast of Brazil (Fernandes 1999; Matni 2007; Silva \& Fernandes 2011; Rodrigues 2015), suggesting that high phenological synchrony is a common characteristic of this genus. Unlike the results of the present study, low (Nadia et al. 2012) or no (Fernandes 1999; Matni 2007) synchrony has been reported for flowering in L. racemosa.

An annual pattern (sensu Newstrom et al. 1994) was observed in the reproductive phenophases of Avicennia germinans, which is common in other Brazilian mangrove forests (Tab. 3). Laguncularia racemosa exhibited annual and subannual patterns for flowering (bud + flower) and fruiting, respectively. To confirm this pattern, monitoring should be carried out for at least two years, because other flowering patterns have been documented for this species (Tab. 4).

In general, A. germinans and L. racemosa showed similar associations to abiotic factors. Solar radiation, temperature and rainfall with a two-month lag triggered flowering in both species studied. At low latitudes, in the absence of a distinct day length signature, this result indicates an adaptation of tropical tree phenology to the annual course of solar radiation (Borchert et al. 2015).

The flowering of mangrove species has been associated with air temperature (Fernandes 1999; Kamruzzaman et al. 2013, 2016; Wang'ondu et al. 2013), as observed in the present study. Latitudinal trends have been observed for the flowering of Avicennia marina in Australian mangroves, because high air temperature was the determining factor stimulating this phenophase and the duration of the reproductive cycle of the species (Duke 1990). However, studies conducted in northeastern Brazil indicated that L. racemosa flowering is not associated with temperature (Nadia et al. 2012; Medeiros \& Sampaio 2013).

Water deficiency with a two-month lag triggered the flowering of $A$. germinans and $L$. 
Table 3 - Reproductive phenological patterns of Avicennia germinans in Brazilian mangrove forests. $\mathrm{D}=\mathrm{dry} ; \mathrm{R}=$ rainy. ${ }^{1}=$ Fernandes (1999); ${ }^{2}=$ Matni $(2007) ;{ }^{3}=$ Rodrigues $(2015) ;{ }^{4}=$ Silva \& Fernandes $(2011) ;{ }^{5}=$ Gardunho (2009); ${ }^{6}=$ Bernini et al. $(2014) ;{ }^{7}=$ Bernini \& Rezende (2010). Flowering = floral buds + flower at anthesis. Fruiting $=$ mature and immature fruits.

\begin{tabular}{|c|c|c|c|c|c|c|c|c|c|}
\hline \multirow[t]{2}{*}{ Site / latitude } & \multirow[t]{2}{*}{ Methods } & \multirow{2}{*}{$\begin{array}{c}\text { Flowering } \\
\text { duration }\end{array}$} & \multirow{2}{*}{$\begin{array}{c}\text { Fruiting } \\
\text { duration }\end{array}$} & \multirow{2}{*}{$\begin{array}{c}\text { Flowering } \\
\text { pattern }\end{array}$} & \multirow{2}{*}{$\begin{array}{c}\text { Fruiting } \\
\text { pattern }\end{array}$} & \multicolumn{2}{|c|}{$\begin{array}{l}\text { Period with } \\
\text { greater } \\
\text { intensity of } \\
\text { flowers }\end{array}$} & \multicolumn{2}{|c|}{$\begin{array}{l}\text { Period with } \\
\text { greater } \\
\text { intensity of } \\
\text { fruits }\end{array}$} \\
\hline & & & & & & D & $\mathbf{R}$ & D & $\mathbf{R}$ \\
\hline $\begin{array}{l}\text { Amapá }^{1} \\
02^{\circ} 10^{\prime} \mathrm{N}\end{array}$ & $\begin{array}{l}\text { Semi-quantitative } \\
\text { (Fernandes 1999) }\end{array}$ & 8 & 9 to 11 & Annual & Annual & $\bullet$ & & & $\bullet$ \\
\hline $\begin{array}{l}\text { Pará }^{2} \\
00^{\circ} 50^{\prime} \mathrm{S}\end{array}$ & $\begin{array}{l}\text { Semi-quantitative } \\
\text { (Fernandes 1999) }\end{array}$ & 5 to 7 & 1 to 4 & Annual & Annual & $\bullet$ & & $\bullet$ & \\
\hline $\begin{array}{l}\text { Pará }^{3} \\
00^{\circ} 50^{\prime} \mathrm{S}\end{array}$ & $\begin{array}{l}\text { Semi-quantitative } \\
\text { (Fernandes 1999) }\end{array}$ & 12 & 9 to 10 & Continuous & Annual & $\bullet$ & & & $\bullet$ \\
\hline $\begin{array}{l}\text { Pará }^{4} \\
00^{\circ} 53^{\prime} \mathrm{S}\end{array}$ & $\begin{array}{l}\text { Semi-quantitative } \\
\text { (Fernandes 1999) }\end{array}$ & 11 & 11 & Continuous & Continuous & $\bullet$ & & & $\bullet$ \\
\hline $\begin{array}{l}\text { Pará }^{5} \\
01^{\circ} 00^{\prime} \mathrm{S}\end{array}$ & $\begin{array}{l}\text { Semi-quantitative } \\
\text { (Fernandes 1999) }\end{array}$ & 9 & 8 & Annual & Annual & $\bullet$ & & $\bullet$ & \\
\hline $\begin{array}{l}\text { This study } \\
06^{\circ} 49^{\prime} \mathrm{S}\end{array}$ & $\begin{array}{c}\text { Quantitative } \\
\text { (Fournier 1974) }\end{array}$ & 8 & 7 & Annual & Annual & $\bullet$ & & & $\bullet$ \\
\hline $\begin{array}{l}\text { Rio de Janeiro }{ }^{6} \\
21^{\circ} 17^{\prime} \mathrm{S}\end{array}$ & $\begin{array}{l}\text { Quantitative } \\
\text { (collectors) }\end{array}$ & 10 & 8 to 9 & Annual & Annual & & $\bullet$ & & $\bullet$ \\
\hline $\begin{array}{l}\text { Rio de Janeiro }{ }^{7} \\
21^{\circ} 36^{\prime} \mathrm{S}\end{array}$ & $\begin{array}{c}\text { Quantitative } \\
\text { (collectors) }\end{array}$ & 5 to 6 & 4 to 5 & Annual & Annual & & $\bullet$ & & $\bullet$ \\
\hline
\end{tabular}

racemosa, showing that hormonal regulation can be an endogenous regulator of flowering (SánchezNuñez \& Mancera-Pineda 2011). Flowering was gradually induced in $A$. germinans by water deficit and it was more intense in the dry season, which coincides with the moment when there is a tendency to reduce interstitial salinity. This species has high photosynthetic water use efficiency (Lovelock \& Feller 2003) and can maintain photosynthetic activity with high interstitial salinity, although with a reduced carbon gain (Sobrado 2006). Thus, during flowering, energy reservoirs or reallocated resources must be utilized to form flowers, with reduced vegetative growth (Sánches-Nuñez \& Mancera-Pineda 2011). On the other hand, flowering was more intense during the rainy season in $L$. racemosa, as reported by several authors (Tab. 4). Unlike that of $A$. germinans, there is a greater intensity of $L$. racemosa flowering during the seasonal growth of the aerial part of the plant and during periods of increased water availability, which allows allocating more resources to flower development (Sánchez-Nuñez \& Mancera-Pineda 2011).

Table 3 shows the phenological pattern of $A$. germinans in Brazilian mangrove forests, in which we verified the tendency for flowering during the dry season in low latitudes and in the rainy season in high latitudes. However, the small number of studies at low latitudes prevents the translation of these trends into a latitudinal pattern. On the other hand, in general, L. racemosa flowering occurs during the rainy season along the Brazilian coast (Tab. 4).

The species showed an association between fruiting and rainfall in this study. Higher fruiting intensity was observed for $L$. racemosa during the rainy season than during the dry season, as previously reported (Tab. 4). Avicennia germinans 
Table 4 - Reproductive phenological patterns of Laguncularia racemosa in Brazilian mangrove forests. $\mathrm{D}=$ dry; $\mathrm{R}=$ rainy ${ }^{1}=$ Fernandes (1999); ${ }^{2}=$ Matni $(2007) ;{ }^{3}=$ Fernandes et al. $(2005) ;{ }^{4}=$ Gardunho (2009); ${ }^{5}=$ Medeiros \& Sampaio (2013); ${ }^{6}=$ Nadia et al. (2012); ${ }^{7}=$ Bernini et al. $(2014) ;{ }^{8}=$ Bernini \& Rezende (2010); ${ }^{9}=$ Rodrigues (2015); ${ }^{10}=$ Cardoso et al. $(2015) ;{ }^{11}=$ Adaime (1985); ${ }^{12}=$ Lima (2012); ${ }^{13}=$ Alvarenga (2015). Flowering = floral buds + flower at anthesis. Fruiting $=$ mature and immature fruits.

\begin{tabular}{|c|c|c|c|c|c|c|c|c|c|}
\hline \multirow[t]{2}{*}{ Site / latitude } & \multirow[t]{2}{*}{ Methods } & \multirow[t]{2}{*}{$\begin{array}{l}\text { Flowering } \\
\text { duration } \\
\text { in the year } \\
\text { (months) }\end{array}$} & \multirow[t]{2}{*}{$\begin{array}{c}\text { Fruiting } \\
\text { duration } \\
\text { in the year } \\
\text { (months) }\end{array}$} & \multirow[t]{2}{*}{$\begin{array}{c}\text { Flowering } \\
\text { pattern }\end{array}$} & \multirow[t]{2}{*}{$\begin{array}{c}\text { Fruiting } \\
\text { pattern }\end{array}$} & \multicolumn{2}{|c|}{$\begin{array}{l}\text { Period with } \\
\text { greater } \\
\text { intensity of } \\
\text { flowers }\end{array}$} & \multicolumn{2}{|c|}{$\begin{array}{l}\text { Period with } \\
\text { greater } \\
\text { intensity of } \\
\text { fruits }\end{array}$} \\
\hline & & & & & & D & $\mathbf{R}$ & D & $\mathbf{R}$ \\
\hline $\begin{array}{l}\text { Amapá }{ }^{1} \\
02^{\circ} 10^{\prime} \mathrm{N}\end{array}$ & $\begin{array}{l}\text { Semi-quantitative } \\
\text { (Fernandez 1999) }\end{array}$ & 9 to 12 & 9 to 12 & Subannual & Subannual & $\bullet$ & & & $\bullet$ \\
\hline $\begin{array}{l}\text { Pará }^{2} \\
00^{\circ} 50^{\prime} \mathrm{S}\end{array}$ & $\begin{array}{l}\text { Semi-quantitative } \\
\text { (Fernandez 1999) }\end{array}$ & 1 to 5 & 2 to 9 & Annual & Annual & $\bullet$ & & & $\bullet$ \\
\hline $\begin{array}{l}\text { Pará }^{3} \\
00^{\circ} 50^{\prime} \mathrm{S}\end{array}$ & $\begin{array}{l}\text { Semi-quantitative } \\
\text { (Fernandez 1999) }\end{array}$ & 11 & 12 & Continuous & Continuous & & $\bullet$ & & $\bullet$ \\
\hline $\begin{array}{l}\text { Pará }^{4} \\
01^{\circ} 00 \text { 'S }\end{array}$ & $\begin{array}{l}\text { Semi-quantitative } \\
\text { (Fernandez 1999) }\end{array}$ & 12 & 12 & Continuous & Continuous & & $\bullet$ & & $\bullet$ \\
\hline $\begin{array}{l}\text { Pernambuco }{ }^{5} \\
07^{\circ} 47^{\prime} \mathrm{S}\end{array}$ & $\begin{array}{c}\text { Quantitative } \\
\text { (Christensen 1978) }\end{array}$ & 5 & - & Annual & Annual & & $\bullet$ & - & - \\
\hline $\begin{array}{l}\text { Pernambuco } \\
07^{\circ} 50^{\prime} \mathrm{S}\end{array}$ & (Fournier 1974) & 6 to 9 & 5 to 10 & Subannual & Subannual & & $\bullet$ & & - \\
\hline $\begin{array}{l}\text { This study } \\
06^{\circ} 49^{\prime} \mathrm{S}\end{array}$ & $\begin{array}{c}\text { Quantitative } \\
\text { (Fournier 1974) }\end{array}$ & 8 & 3 & Annual & Subannual & & $\bullet$ & & $\bullet$ \\
\hline $\begin{array}{l}\text { Rio de Janeiro }{ }^{7} \\
21^{\circ} 17^{\prime} \mathrm{S}\end{array}$ & $\begin{array}{r}\text { Quantitative } \\
\text { (collectors) }\end{array}$ & 3 & 2 to 4 & Annual & Annual & & $\bullet$ & & $\bullet$ \\
\hline $\begin{array}{l}\text { Rio de Janeiro }{ }^{8} \\
21^{\circ} 36^{\prime} \mathrm{S}\end{array}$ & $\begin{array}{l}\text { Quantitative } \\
\text { (collectors) }\end{array}$ & 4 & 4 & Annual & Annual & & $\bullet$ & & $\bullet$ \\
\hline $\begin{array}{l}\text { Rio de Janeiro }{ }^{9} \\
22^{\circ} 42^{\prime} \mathrm{S}\end{array}$ & $\begin{array}{c}\text { Quantitative } \\
\text { (Fournier 1974) }\end{array}$ & 8 & 8 to 10 & Annual & Annual & & $\bullet$ & & $\bullet$ \\
\hline $\begin{array}{l}\text { Rio de Janeiro }{ }^{10} \\
23^{\circ} 00^{\prime} \mathrm{S}\end{array}$ & $\begin{array}{l}\text { Quantitative } \\
\text { (collectors) }\end{array}$ & - & 2 to 6 & - & Subannual & - & - & & $\bullet$ \\
\hline $\begin{array}{l}\text { São Paulo }{ }^{11} \\
25^{\circ} 00^{\prime} \mathrm{S}\end{array}$ & $\begin{array}{r}\text { Quantitative } \\
\text { (collectors) }\end{array}$ & 3 & 7 & Annual & Annual & & $\bullet$ & & $\bullet$ \\
\hline $\begin{array}{l}\text { Paraná }^{12} \\
25^{\circ} 29^{\prime} \mathrm{S}\end{array}$ & $\begin{array}{c}\text { Quantitative } \\
\text { (Fournier 1974) }\end{array}$ & 12 & 7 & Continuous & Annual & & $\bullet$ & & $\bullet$ \\
\hline $\begin{array}{l}\text { Paraná }^{13} \\
25^{\circ} 49^{\prime} \mathrm{S}\end{array}$ & $\begin{array}{c}\text { Quantitative } \\
\text { (Fournier 1974) }\end{array}$ & 8 & 3 & Annual & Annual & & $\bullet$ & & $\bullet$ \\
\hline
\end{tabular}

showed greater intensity of fruiting during the transition between dry and rainy seasons. Other studies have shown greater intensity during the rainy season (Tab. 4). Latitudinal patterns in fruit production have been described for 47 mangrove species, with significant association between fruiting and rainfall (Van der Stoken et al. 2017). As mangrove species are hydrocoric, the rainy season is favorable for fruit dispersion, survival, and seedling establishment (Duke et al. 1984). 
The results of the present study of a degraded mangrove forest may be useful for restoration initiatives that require propagule collection for no-till or seedling production. We recommend that these propagules be collected when fruiting intensity is high, that is, mainly from February to May for A. germinans and from May to June for L. racemosa.

In conclusion, the present study demonstrated that $A$. germinans exhibits seasonal responses to floral buds, flowers at anthesis, and fruit and $L$. racemosa has no seasonal response. The results showed that the species exhibited different phenological responses, even though they were subjected to the same abiotic conditions.

\section{Acknowledgments}

The authors thank CNPq (the Brazilian National Council for Scientific and Technological Development), for the scientific initiation scholarship granted to the second author. We thank the Federal University of Paraíba, for providing transportation support for field activities. We thank the anonymous reviewers, for recommendations that have considerably improved the quality of this paper.

\section{References}

Adaime RR (1985) Produção do bosque de mangue da Gamboa Nóbrega (Cananéia, 25 Lat. S. Brasil). Tese de Doutorado. Universidade de São Paulo, São Paulo. 305p.

Agostinelli C \& Lund U (2017) R package 'circular': circular statistics. R package version 0.4-93. Available at $<$ https://r-forge.r-project.org/projects/ circular/>. Access on 3 November 2018.

Alvarenga AMSB (2015) Dinâmica de crescimento das espécies arbóreas de um manguezal no sul do Brasil. Dissertação de Mestrado. Universidade Federal do Paraná, Curitiba. 64p.

Alvares CA, Stape JL, Sentelhas PC, Moraes G, Leonardo J \& Sparovek G (2013) Köppen's climate classification map for Brazil. Meteorologische Zeitschrift 22: 711-728.

Augspurger CK (1983) Phenology, flowering synchrony, and fruit set of six neotropical shrubs. Biotropica 15: 257-267.

Bernini E, Chagas T, Lage-Pinto F, Calegario G \& Rezende CE (2014) Phytosociology and litterfall in the mangrove estuary of the Itabapoana river, Southeast Brazil. Pan-American Journal of Aquatic Sciences 9: 88-102.

Bernini E \& Rezende CE (2010) Litterfall in a mangrove in Southeast Brazil. Pan-American Journal of Aquatic Sciences 5: 508-519.
Bencke CC \& Morellato LPC (2002) Estudo comparativo da fenologia de nove espécies arbóreas em três tipos de floresta atlântica no sudeste do Brasil. Revista Brasileira de Botanica. Brazilian Journal of Botany 25: 237-248.

Borchert R, Calle Z, Strahler AH, Baertschi A, Magill RE, Broadhead JS, Kamau J, Njoroge J \& Muthuri C (2015) Insolation and photoperiodic control of tree development near the equator. New Phytologist 205: 7-13.

Cardoso CS, Chaves FO \& Soares MLG (2015) Variação espaço-temporal na produção de propágulos de espécies de mangue no Sudeste do Brasil. Boletim do Museu Paraense Emílio Goeldi. Ciências Naturais 10: 491-503.

Couralet C, Van den Bulcke J, Ngoma LM, Van Acker J \& Beeckman H (2013) Phenology in functional groups of central African rainforest trees. Journal of Tropical Forest Science 25: 361-374.

Duke NC (1990) Phenological trends with latitude in the mangrove tree Avicennia marina. Journal of Ecology 78: 113-133.

Duke NC, Bunt JS \& Williams WT (1984) Observations on the floral and vegetative phenologies of Northeastern Australian Mangroves. Australian Journal of Botany 32: 87-99.

Encinas-Viso F, Revilla TA \& Etienne RS (2012) Phenology drives mutualistic network structure and diversity. Ecology Letters 15: 198-208.

Fenner M (1998) The phenology of growth and reproduction in plants. Perspectives in Plant Ecology, Evolution and Systematics 1: 78-91.

Fernandes MEB (1999) Phenological patterns of Rhizophora L., Avicennia L. and Laguncularia Gaertn. f. in Amazonian mangrove swamps. Hydrobiologia 413: 53-62.

Fernandes MEB, Virgulino ARC, Nascimento AAM \& Rodrigues LFP (2005) Padrões de floração e frutificação em Laguncularia racemosa (L.) Gaertn. f.: uma avaliação metodológica. Boletim do Laboratório de Hidrobiologia 18: 33-38.

Fournier LA (1974) Un método cuantitativo para la medición de características fenológicas em árboles. Turrialba 24: 54-59.

Garcia LC, Barros FV \& Lemos-Filho JP (2009) Fructification phenology as an important tool in the recovery of iron mining areas in Minas Gerais, Brazil. Brazilian Journal of Biology 69: 887-893.

Gardunho DCL (2009) Atributos estruturais e fenologia dos manguezais da reserva extrativista marinha de Soure, Ilha do Marajó, Pará. Dissertação de Mestrado. Universidade Federal do Pará, Bragança. $69 \mathrm{p}$.

Harris IC \& Jones PD (2020) University of East Anglia Climatic Research Unit. CRU TS4.03: Climatic Research Unit (CRU) Time-Series (TS) version 4.03 of high-resolution gridded data of month-bymonth variation in climate (Jan. 1901-Dec. 2018). 
Centre for Environmental Data Analysis, 22 January 2020. Available at $<$ http://dx.doi.org/10.5285/10d3 e3640f004c578403419aac167d82>. Access on 06 February 2020. DOI:10.5285/10d3e3640f004c578 403419 aac $167 \mathrm{~d} 82$.

ICMBio (2014) Plano de Manejo para a Área de Proteção Ambiental da Barra do Rio Mamanguape e Área de Relevante Interesse Ecológico de Manguezais da Foz do Rio Mamanguape. The Ministry of Environment, Brasilia, Brazil. Available at $<$ http://www.icmbio. gov.br/portal/images/stories/docs-planos-demanejo/apa_arie_manguezais_mamanguape 2014 . pdf $>$. Access on 3 November 2018.

Jammalamadaka RS \& SenGupta A (2001) Topics in circular statistics. World Scientific, Singapore. 322p.

Kamruzzaman MD, Kamara M, Sharma S \& Hagihara A (2016) Stand structure, phenology and litterfall dynamics of a subtropical mangrove Bruguiera gymnorrhiza. Journal of Forestry Research 27: 513-523.

Kamruzzaman MD, Paul SK, Ahmed S, Azad MDS \& Kamruzzaman AO (2019) Phenology and litterfall production of Bruguiera sexangula (Lour.) Poir. in the Sundarbans mangrove forests, Bangladesh. Forest Science and Technology 15: 165-172.

Kamruzzaman MD, Sharma S, Kamara M \& Hagihara A (2013) Vegetative and reproductive phenology of the mangrove Bruguiera gymnorrhiza (L.) Lam. on Okinawa Island, Japan. Trees 27: 619-628.

Kovach WL (2011) Oriana - Circular Statistics for Windows. Version. 4.02. Kovach Computing Services, Pentraeth. Available at $<$ https://www. kovcomp.co.uk/downl2.html>. Access on 06 February 2020.

Liebsch D \& Mikich SB (2009) Fenologia reprodutiva de espécies vegetais da Floresta Ombrófila Mista do Paraná, Brasil. Revista Brasileira de Botânica 32: 375-391.

Lima CS (2012) Morfologia foliar e fenologia do componente arbóreo de manguezais das Baías de Guaratuba e Antonina, Paraná, Brasil. Dissertação de Mestrado. Universidade Federal do Paraná, Curitiba. 53p.

Lovelock CE \& Feller IC (2003) Photosynthetic performance and resource utilization of two mangrove species coexisting in a hypersaline scrub forest. Oecologia 134: 455-462.

Matni AS (2007) Estudo comparativo da fenologia reprodutiva de Rhizophora mangle L., Avicennia germinans (L.) Stearn e Laguncularia racemosa (L.) Gaertn. f., ao longo da península de Ajuruteua, Bragança, Pará. Dissertação de Mestrado. Universidade Federal do Pará, Bragança. 48p.

Medeiros TCC \& Sampaio EVSB (2013) Leaf and flower formation in shoot tips of mangrove trees in Pernambuco, Brazil. Wetlands Ecology and Management 21: 209-217.
Morellato LPC (2008) Fenologia de plantas e os efeitos das mudanças climáticas. In: Buckeridge MS (ed.) Biologia \& Mudanças Climáticas no Brasil. RiMa, São Carlos. Pp. 181-191.

Morellato LPC, Alberton B, Alvarado ST, Borges B, Buisson E, Camargo MGG, Cancian LF, Carstensen DW, Escobar DFE, Leite PTP, Mendoza I, Rocha NMWB, Soares NC, Silva TSF, Staggemeier VG, Streher AS, Vargas BC \& Peres CA (2016) Linking plant phenology to conservation biology. Biological Conservation 195: 60-72.

Morellato LPC, Camargo MGG, D’Eça Neves FF, Luize BG, Mantovani A \& Hudson IL (2010) The influence of sampling method, sample size, and frequency of observations on plant phenological patterns and interpretation in tropical forest trees. In: Hudson IL \& Keatley MR (eds.) Phenological research: methods for environmental and climate change analysis. Springer, Amsterdam. Pp. 99-122.

Morellato LPC, Camargo MGG \& Gressler E (2013) A review of plant phenology in south and central America. In: Dordrecht MD (ed.) Phenology: an integrative environmental science. Springer, Schwartz. Pp. 91-113.

Morellato LPC, Romera EC, Talora DC, Takahashi A, Bencke CC \& Zipparro VB (2000) Phenology of Atlantic Rain Forest trees: a comparative study. Biotropica 32: 811-823.

Nadia TL, Morellato LPC \& Machado IC (2012) Reproductive phenology of a northeast Brazilian mangrove community: environmental and biotic constraints. Flora 207: 682-692.

Nascimento-Costa EC (2015) Aspectos estruturais de uma floresta de mangue submetida à corte seletivo na Área de Proteção Ambiental da Barra do Rio Mamanguape, estado da Paraíba. Trabalho de conclusão de curso. Universidade Federal da Paraíba, Rio Tinto. 41p.

Newstrom LE, Frankie GW \& Baker HG (1994) A new classification for plant phenology based on flowering patterns in lowland tropical rain forest trees at $\mathrm{La}$ Selva, Costa Rica. Biotropica 26: 141-159.

NASA (2020) Data-access-viewer. Available at $<$ https:// power.larc.nasa.gov/beta/data-access-viewer/>. Access on February 2020.

R Core Team (2018) R: a language and environment for statistical computing. Version 3.5.2. R Foundation for Statistical Computing, Vienna. Available at $<$ https://www.R-project.org/>. Access on 11 December 2018.

Revilla TA, Encinas-Viso F \& Loreau M (2014) Robustness of mutualistic networks under phenological change and habitat destruction. Oikos 124: 22-32.

Rodrigues GA (2015) Aspectos fenológicos e produção de mudas de três espécies nativas do ecossistema manguezal. Dissertação de Mestrado. Universidade Federal do Rio de Janeiro, Rio de Janeiro. 57p. 
Rodríguez-Gallego C \& Navarro T (2015) Vegetative and reproductive phenological patterns in coastal dunes in S Spain. Anales del Jardín Botánico de Madrid 72:e017. Available at <https://doi. org/10.3989/ajbm.2371>. Access on 15 October 2018.

Sánchez-Núnez DA \& Mancera-Pineda JE (2011) Flowering patterns in three neotropical mangrove species: evidence from a Caribbean island. Aquatic Botany 94: 177-182.

Silva LL \& Fernandes MEB (2011) Relação entre os atributos estruturais das árvores de Avicennia germinans (L.) Stearn e sua fenologia reprodutiva. Boletim do Laboratório de Hidrobiologia 24: 51-57.

Sobrado MA (2006) Differential leaf gas exchange responses to salinity and drought in the mangrove tree Avicennia germinans (Avicenniaceae). Revista de Biologia Tropical 54: 371-375.

Ulsig L, Nichol CJ, Huemmrich KF, Landis DR, Middleton EM, Lyapustin AI, Mammarella I, Levula J \& Porcar-Castell A (2017) Detecting interannual variations in the phenology of evergreen conifers using long-term MODIS vegetation index time series. Remote Sensing 9:e49. Available at
$<$ https://doi.org/10.3390/rs9010049>. Access on 13 October 2018.

Van der Stocken T, López-Portillo J \& Koedam N (2017) Seasonal release of propagules in mangroves Assessment of current data. Aquatic Botany 138: 92-99.

Wang X (2015) Flower: tools for characterizing flowering traits. R package version 1.0. Available at $<$ https:// CRAN.R-project.org/package $=$ flower $>$. Access on 11 December 2018.

Wang'ondu VW, Kairo JG, Kinyamario JI, Mwaura FB, Bosire JO, Dahdouh-Guebas F \& Koedam N (2013) Vegetative and reproductive phenological traits of Rhizophora mucronata Lamk. and Sonneratia alba Sm. Flora 208: 522-531.

Wolkovich EM, Cook BI \& Davies TJ (2014) Progress towards an interdisciplinary science of plant phenology: building predictions across space, time and species diversity. New Phytologist 201: 1156-1162.

Zamith LR \& Scarano FR (2004) Produção de mudas de espécies das Restingas do município do Rio de Janeiro, RJ, Brasil. Acta Botanica Brasilica 18: 161-176.

Zar HJ (2010) Biostatistical Analysis. 5th ed. Pearson Prentice Hall, New Jersey. 944p. 